\title{
Theory of island biogeography on a microscopic scale: organic aggregates as islands for aquatic pathogens
}

\author{
M. M. Lyons ${ }^{1,2, *}$, J. E. Ward ${ }^{1}$, H. Gaff ${ }^{3}$, R. E. Hicks ${ }^{4}$, J. M. Drake ${ }^{5}$, F. C. Dobbs ${ }^{2}$ \\ ${ }^{1}$ Department of Marine Sciences, University of Connecticut, Groton, Connecticut 06340, USA \\ ${ }^{2}$ Department of Ocean, Earth and Atmospheric Sciences, and ${ }^{3}$ College of Health Sciences, Old Dominion University, \\ Norfolk, Virginia 23529, USA \\ ${ }^{4}$ Department of Biology, University of Minnesota Duluth, Duluth, Minnesota 55812, USA \\ ${ }^{5}$ Institute of Ecology, University of Georgia, Athens, Georgia 30602-2602, USA
}

\begin{abstract}
Four predictions of the MacArthur-Wilson theory of island biogeography were evaluated to assess the degree to which detrital-based organic aggregates (e.g. marine snow, organic detritus, and bioflocs) may provide a favorable microhabitat (i.e. an 'island') for bacteria in general, and specifically aquatic pathogens. We demonstrate the theory's relevance for microbial communities in aquatic environments by describing the community metabolic response and functional diversity of individual organic aggregates while documenting the persistence of potential pathogens and fecal indicator bacteria. Our results support the 4 predictions, including a significant species-area relationship, consistency of species richness at equilibrium, non-zero level of species turnover at equilibrium, and variance to mean ratios of less than 0.5 at equilibrium. The aggregate-associated microbial communities demonstrated significantly higher rates of metabolic response and functional diversity, and contained higher concentrations of culturable vibrios and fecal indicator bacteria compared to aggregate-free water, supporting the idea that organic aggregates are sites of favorable habitat surrounded by a less favorable matrix. These results substantiate that organic aggregates may be represented as microscopic islands. Using island biogeography theory to understand the microbial ecology of aquatic pathogens associated with organic aggregates is important with respect to environmental sampling of recreational waters and mathematical modeling of the transmission of waterborne diseases from aquatic reservoirs to humans.
\end{abstract}

KEY WORDS: Organic aggregates - Island biogeography · Functional diversity - Aquatic pathogens - Vibrio • Fecal indicator bacteria written consent of the publisher

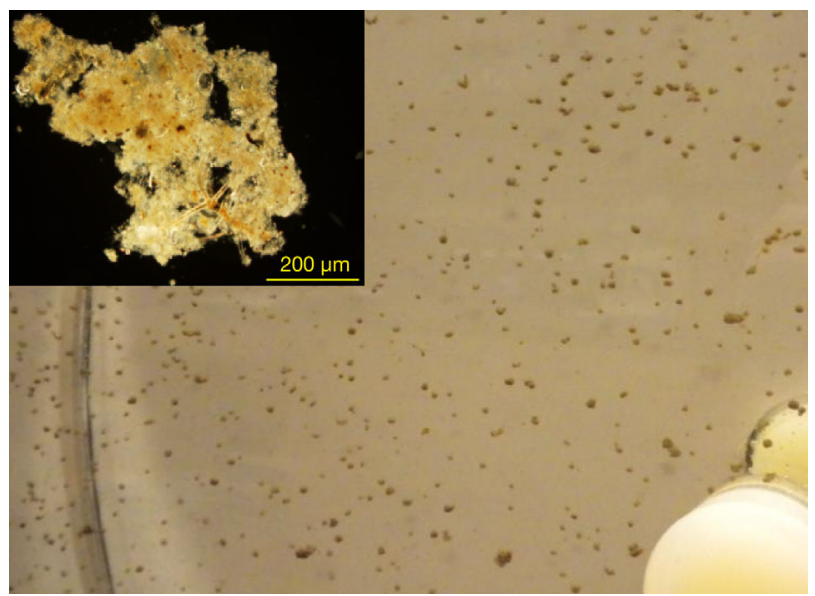

Organic aggregate (light micrograph inset and dark spots in main photo) produced in $10 \mathrm{l}$ rotating tanks function as islands for aquatic bacteria, including potential pathogens

Photo: M. M. Lyons

\section{INTRODUCTION}

The term 'organic aggregate' is a general expression that encompasses multiple kinds of aggregated material suspended in aquatic systems, including marine, lake and river snow, macro- and microaggregates, organic detritus, flocs and bioflocs (see Fig. 1A,C,D). Aggregation of living, dead, and inorganic particles in aquatic ecosystems is a natural process influenced by numerous biological, chemical, and physical interactions, and affects the net transport of carbon, nutrients, metals, and other materials from the water column to 
benthic habitats (Fowler \& Knauer 1986). For decades the biology and ecology of organic aggregates has been studied in the context of oceanography (e.g. Alldredge 1979, Silver \& Alldredge 1981, Alldredge \& Cohen 1987, Lampitt et al. 1993, Azam \& Long 2001), environmental microbiology (e.g. Riley 1963, Caron et al. 1986, Logan \& Hunt 1987, Herndl 1988, Azam et al. 1994, Kiørboe 2003, Grossart et al. 2006, Yam \& Tang 2007), the distribution of metals (e.g. Cowen \& Silver 1984, Hebel et al. 1986), phytoplankton ecology (Riebesell 1991, Kaltenböck \& Herndl 1992, Kiørboe \& Hansen 1993, Silver et al. 1998, Thornton 2002), mesoplankton and benthic trophic interactions (e.g. Bochdansky \& Herndl 1992, Alber \& Valiela 1996, Shanks \& Walters 1997, Kiørboe \& Thygesen 2001), and carbon and nutrient cycling (e.g. Shanks \& Trent 1979, Cho \& Azam 1988, Alldredge \& Gotschalk 1990, Brzezinski et al. 1997, Ploug et al. 1999, Alldredge 2000, Kiørboe 2001). Detailed reviews of the processes governing aggregation (Eisma et al. 1991, Jackson \& Burd 1998, Burd \& Jackson 2009) and the microbial ecology of aggregates (Alldredge \& Silver 1988, Simon et al. 2002, Turner 2002) have summarized the breadth of information regarding these ubiquitous and dynamic conglomerations of living and nonliving particles.

Although the importance of marine, estuarine, and freshwater aggregates continues to be an area of active research (e.g. Guidi et al. 2008, Kach \& Ward 2008, Ploug et al. 2008, Stemmann et al. 2008, Engel et al. 2009, Stevens et al. 2009, Ward \& Kach 2009), the role of organic aggregates in the ecology of aquatic pathogens is only now beginning to be evaluated (Lyons et al. 2007, Lyons 2008). For example, aggregates have been shown to be an environmental reservoir for the eukaryotic hard clam pathogen, Quahog Parasite X (QPX; Lyons et al. 2005, Lyons 2008), and to contain Vibrio parahaemolyticus (Venkateswaran et al. 1990) and V. cholerae (Colwell et al. 2003). Elsewhere, Lyons et al. (2007) also found these 2 bacterial species in aggregates and expanded the list of potentially harmful, aggregate-associated bacteria to include: $V$. vulnificus, V. alginolyticus, Escherichia coli, Enterococcus sp., Mycobacterium sp., Aeromonas hydrophila, Pseudomonas aeruginosa, Photobacterium damselae, Shigella sonnei, Stenotrophomonas maltophila, and Burkholderia cepacia. These species include potential pathogens (and pathogen indicators) associated with sewage-related pollution events and natural aquatic microbial communities, yet little is known about the community ecology of aggregates with respect to these pathogens.

A fundamental part of disease risk is exposure. Accordingly, to understand the disease risk presented by aggregate-associated pathogens, it is important to understand the processes that determine the number and diversity of species associated with an aggregate or collection of aggregates. In this study, we adopt the theory of island biogeography (MacArthur \& Wilson $1963,1967)$ as a conceptual framework for understanding the accumulation of bacterial species on aggregates. Originally, island biogeography theory was developed to explain the composition of biological communities found on oceanic islands. The theory predicts a dynamic equilibrium between colonization of new species and extinction of resident species in which the total number of species (i.e. species richness) is an increasing function of island size and a decreasing function of the distance to a source of potential colonizers (e.g. continental mainland). Previous applications include the species richness of birds on California's Channel Islands (Diamond 1969, Jones \& Diamond 1976) and of ants within the Malaysian Archipelago (Wilson 1959), re-colonization of islands following volcanic eruptions (Krakatau Islands; Bush \& Whittaker 1991, Thornton 1996), and intentional depopulations (mangrove islands in Florida Keys; Simberloff \& Wilson 1970). More recently the theory of island biogeography has been extended to other ecosystems with highquality habitat surrounded by less-suitable habitat, such as mountains bounded by deserts (Lomolino et al. 1989, Kebede et al. 2007), and ecological reserves encircled by urban environments (Fore \& Guttman 1999, Ohmura et al. 2006). In contrast with the many applications of island biogeography to macro-organisms, the theory has seldom been tested on a smaller scale for microbial communities (for exceptions see Kinkel et al. 1987, Bell et al. 2005, Reche et al. 2005), and to our knowledge, not in the context of disease ecology.

Here, we argue the theory's relevance for microbial communities in aquatic environments by describing the community metabolic response and functional diversity of individual organic aggregates while monitoring the persistence of potential pathogens and fecal indicator bacteria. Four predictions of island biogeography theory were evaluated including (1) speciesarea relationship, (2) consistency of the number of species, (3) degree of species turnover, and (4) variance to mean ratio of species diversity at equilibrium (Gilbert 1980, Brown \& Dinsmore 1988). Other predictions of the theory, including the distance from a source and colonization of new (e.g. sterilized) islands, are the focus of ongoing experiments not described in this paper. Our long-term objective is to apply this community-level approach to the study of waterborne diseases and illnesses by evaluating the degree to which detrital-based organic aggregates may provide a favorable micro-habitat (i.e. an 'island') for aquatic pathogens. If so, aggregates may facilitate persistence, prevalence, and dispersal of aquatic pathogens in 
nature. Furthermore, an improved understanding of the processes involved will inform and influence environmental sampling and mathematical modeling of aquatic pathogens.

\section{MATERIALS AND METHODS}

Source water. Surface water (15 l, salinity 15 psu) was collected from Knitting Mill Creek (KMC), Virginia, USA $\left(36.89^{\circ} \mathrm{N}, 76.29^{\circ} \mathrm{W}\right)$. The creek is a small branch of the Lafayette River, a tributary of the Elizabeth River, which ultimately empties into the mouth of the Chesapeake Bay. Water was collected in a sterile container from an area near $(\sim 1 \mathrm{~m})$ a storm-water drainage pipe.

Generation of aggregates. Aggregates (Fig. 1A, $\mathrm{C}, \mathrm{D})$ were generated in a rotating $10 \mathrm{l}$ cylindrical tank (Fig. 1B, $40 \mathrm{~cm}$ diameter, $8 \mathrm{~cm}$ width) modified from Shanks \& Edmonson (1989). The tank was filled with source water (well mixed) and rolled at $1.5 \mathrm{rpm}$ for 35 $\mathrm{d}$ at room temperature.

Aggregate sampling. On Days 1, 2, 7, 14, and 35 the tank was temporarily removed from the rolling table and placed horizontally on a calibrated white background for photography (see 'Materials and methods:
Image analysis') and sample collection. Individual aggregates $(\mathrm{n}=6)$ of similar size ( 2 to $4 \mathrm{~mm}$ long axis) were collected, one at a time, through the tank's center port with minimal surrounding water $(<0.1 \mathrm{ml})$ using sterile $1 \mathrm{ml}$ disposable pipettes. Individual aggregates were then transferred to labeled $15 \mathrm{ml}$ centrifuge tubes in which each aggregate was diluted to $10 \mathrm{ml}$ with sterile (autoclaved and $0.2 \mu \mathrm{m}$ filtered) $\mathrm{KMC}$ water. This dilution was used for both the community composition analysis and the culturable vibrios assay (see sections 'Microbial community composition' and 'Concentration of culturable vibrios (TCBS)'). A total of 30 samples (i.e. $5 \mathrm{~d} \times 6$ aggregates per day) were used for all statistical analyses of aggregate data . Additional aggregates ( $n=3$ ) were collected to evaluate the concentration of Escherichia coli in the aggregate-associated microbial communities (total $n=15$ ).

Water sampling. Water samples with no aggregates visible to the naked eye (i.e. operationally defined 'aggregate-free' water) were collected from the center port of the tank using sterile $10 \mathrm{ml}$ disposable pipettes. The starting water (Day 0 for both aggregate and aggregatefree samples) included 1 sample based on 3 replicates, whereas on all other days, 6 samples (10 ml each) were collected for determination of community composition and concentration of culturable vibrios. These water

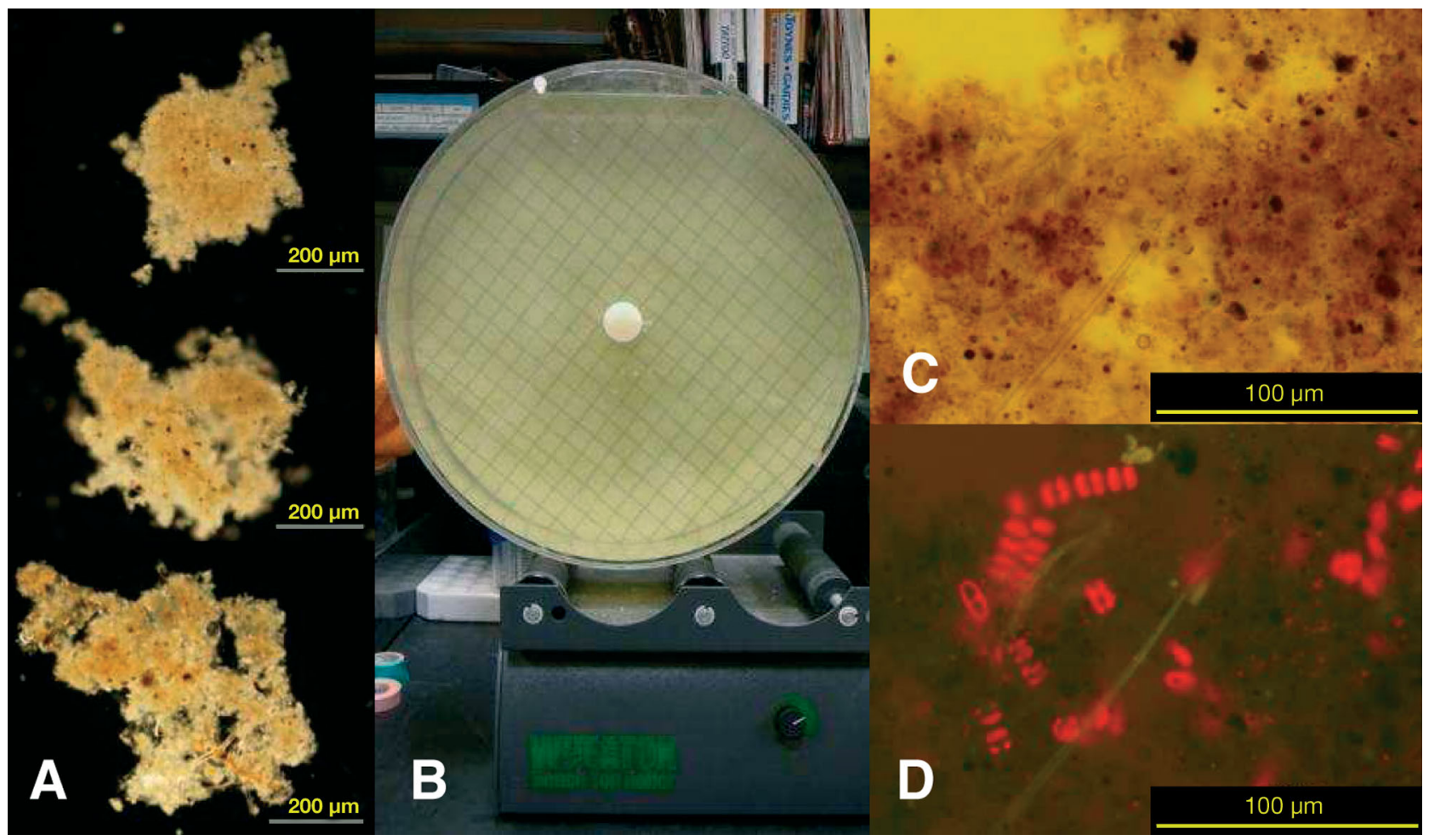

Fig. 1. (A) Concurrently created aggregates typically differing in size, shape, and complexity. (B) Aggregates were made from natural waters in large cylindrical tanks (diameter $=40 \mathrm{~cm}$ ) that were rotated (1 to $2 \mathrm{rpm}$ for 1 to $35 \mathrm{~d}$ ) on bench top roller tables (Shanks \& Edmonson, 1989). Resulting aggregates contained a variety of plankton as seen with a microscope under (C) transmitted light and (D) with epifluorescent blue-light excitation (same field as C) 
samples were processed without dilution. A total of 31 water samples $(5 \mathrm{~d} \times 6$ samples per day, plus 1 initial water sample) were collected and used for statistical analysis with the exception of the assessment of community metabolic response and functional diversity for which 28 samples were used (due to loss of 3 samples during processing). Additional $10 \mathrm{ml}$ samples $(\mathrm{n}=3$ ) were collected on each sampling day to evaluate the concentration of Escherichia coli in the aggregate-free microbial communities (total $\mathrm{n}=18$ ). After sampling was completed, a similar volume of sterile KMC water ( $90 \mathrm{ml}$ ) was added back to the tank to maintain a constant volume. Although this additional water diluted the microbial community in the 101 tank, the effect is likely to be small given the size of the tank relative to the amount of the water added (i.e. $<1 \%$ per time point).

Image analysis. With the tank in the horizontal position, individual aggregates were photographed and analyzed using previously developed image analysis procedures for marine aggregates (Lyons et al. 2007). Digital color photographs were uploaded to an image analysis program (ImageJ; available at http://rsbweb. nih.gov) and converted to 8-bit gray scale. Aggregates were identified, numbered, counted, and sized using a binary threshold and an automated particle counter. Results were manually verified against the original photographs (Fig. 2A-D). Several metrics of size, including long and short axes, surface area, and perimeter were recorded. Volumes of individual aggregates were calculated using the long and short axes of each aggregate and the equation for volume $(V)$ of an ellipsoid ( $V=4 / 3 \pi a b^{2} ;$ a: $1 / 2$ long axis, b: $1 / 2$ short axis).

Microbial community composition. Biolog EcoPlate $^{\mathrm{TM}}$ microplates (Biolog, Inc.) were used to characterize and compare the aggregate-associated and

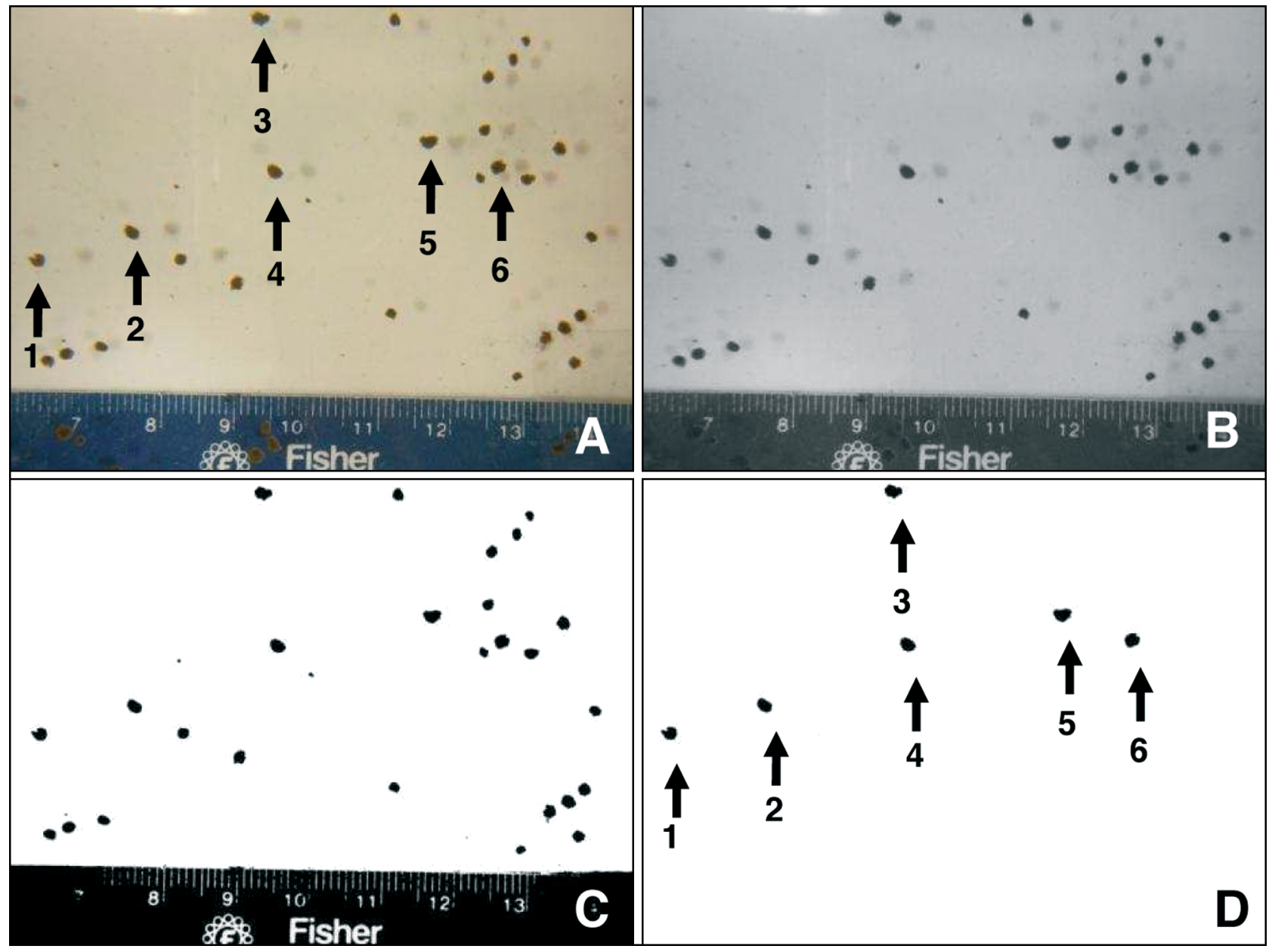

Fig. 2. Individual aggregates were measured (e.g. long axis, surface area, volume) via image analysis prior to being collected with sterile $1 \mathrm{ml}$ disposable pipettes. Selected aggregates (1 to 6) were identified on digital color photographs (A) before being converted to an 8-bit gray-scale (B). A binary threshold was used to produce dark particles on a light background $\left(\mathrm{C}_{i}\right.$ notice shadows, located to the right of aggregates [in A,B], were eliminated by this procedure). An automatic particle analyzer (ImageJ) was used to determine the size of selected aggregates (D), the locations of which were then verified against the original photographs 
aggregate-free heterotrophic microbial communities. EcoPlate $^{\mathrm{TM}}$ microplates consist of 3 replicate sets of 31 carbon substrates (see Table 1), predominantly amino acids, carbohydrates, and carboxylic acids, individually arrayed in a 96-well format. Each well also contains a minimal growth medium and tetrazolium violet dye. The redox dye turns purple in the presence of electron transfer, indicating utilization of the substrate by inoculated microbes (Bochner 1989). A control well contains no sole-carbon substrate, thus any color development indicates utilization of carbon sources inherent in the inoculated water or storage polymers of microbes. EcoPlate ${ }^{\mathrm{TM}}$ microplates have been shown to be effective at discriminating among aquatic heterotrophic microbial communities (Choi \& Dobbs 1999). Preliminary experiments (data not shown) revealed that pooling aggregates prior to dilution yielded consistent results among replicate wells, but that diluting a single aggregate to the necessary volume required to fill all 96 wells of an EcoPlate ${ }^{\mathrm{TM}}$ did not (presumably because excessive dilution reduced heterotrophic expression of the microbial community below threshold levels). Consequently, individual aggregates were only diluted enough to fill one set of 32 wells per plate. Samples of aggregates (diluted) and aggregate-free water (undiluted) were vigorously shaken and vortexed (30 s) before $150 \mu$ l aliquots were inoculated into each well. Optical density $(\lambda=$ $590 \mathrm{~nm}$ ) of each well was determined immediately (time $=0 \mathrm{~h}$ ) and after $3 \mathrm{~d}$ (time $=72 \mathrm{~h}$ ) of dark incubation at room temperature $\left(20^{\circ} \mathrm{C}\right)$ with a BioTek plate reader (model ELX800, BioTek). Bacterial concentrations of the aggregates and aggregate-free water were not determined. Christian \& Lind (2006) showed no correlation, after $72 \mathrm{~h}$ incubation, between optical density of wells and bacterial concentration of the starting inoculum (i.e. if the community can utilize a substrate, it will have done so by then). Average well color development (AWCD, measure of average community metabolic response) was calculated in accordance with Garland \& Mills (1991) after subtracting the starting values of each EcoPlate ${ }^{\mathrm{TM}}$ microplate from its $72 \mathrm{~h}$ readings $(\triangle \mathrm{AWCD})$ to account for intrinsic differences in the absorbance of the carbon substrates (Insam \& Goberna 2004). The average ( $\mathrm{n}=6$ per time point) $\triangle$ AWCD (i.e. difference between times 0 and 72 h) was used to assess and compare community metabolic response and functional diversity of microbial communities in aggregates and aggregate-free water samples. The number of substrates utilized by the microbial community of the sample (i.e. a measure of functional diversity, Zak et al. 1994) was determined by comparing the change in well color development (adjusted for the control well) to a threshold value (0.250 optical density). Readings greater than the threshold were counted as substrates used by the community in the sample, whereas readings less than or equal to the threshold value were scored as substrates not used. Species turnover was assessed by comparing the specific substrates used by the aggregate-associated communities at each of 4 consecutive time points (Days $0,1,2,7$ ) when no significant differences were detected in the number of substrates used (i.e. equilibrium, see section 'Results'). To do so, $\triangle$ AWCD values of the 6 aggregates at each time point were averaged, then compared to the threshold (as described above) to determine if the substrate was utilized or not utilized. Finally, variance to mean ratios of the functional diversity (i.e. number of substrates used) of aggregate-associated microbial communities were calculated for each set of 6 aggregates collected at each of the 4 time points.

Concentration of culturable vibrios (TCBS). Triplicate $100 \mu \mathrm{l}$ aliquots of the $10 \mathrm{ml}$ dilutions of individual aggregates $(\mathrm{n}=6)$ and the $10 \mathrm{ml}$ samples of undiluted aggregate-free water $(n=6)$, were spread-plated onto individual thiosulfate citrate bile salts sucrose (TCBS) agar plates. Plates were incubated overnight at $35^{\circ} \mathrm{C}$, after which colony forming units (CFUs) of sucrose-fermenting vibrios (i.e. yellow colonies) and total vibrios (i.e. yellow and green colonies) were counted and recorded. Sucrose-fermenting species of the genus Vibrio comprise several potential pathogens including, $V$. cholerae, $V$. alginolyticus, $V$. harveyi, $V$. cincinnatiensis, V. fluvialis, V. furnissi, and $V$. metschnikovii.

Concentration of fecal indicator bacteria (Escherichia coli). Triplicate samples of aggregates (diluted 1:999) and aggregate-free water (diluted 1:9) were analyzed for E. coli using Colilert-18 (IDEXX Laboratories) to enumerate most probable number (MPN) values for $E$. coli in the aggregate-associated and aggregate-free microbial communities.

Statistical analysis. We used Minitab ${ }^{\circledR}$ for all statistical tests. When exploring a functional or predictive relationship between variables, we used regression analysis (general linear model, GLM), whereas when estimating their degree of association, we used correlation analysis (Sokal \& Rohlf 1981). We analyzed aggregate sizes using 1-way ANOVA (factor was Day). We tested average community metabolic response, functional diversity, and bacterial concentrations using 2 -way ANOVA (with interaction); factors were Day $(0$, $1,2,7,14$, and 35) and Sample type (aggregates and water). Counts of bacteria (vibrios and E. coli) were not normally distributed and were log-transformed before ANOVA. All counts $<1$ colony forming unit (CFU) $\mathrm{ml}^{-1}$ or $<1$ most probable number (MPN) $\mathrm{ml}^{-1}$ were assigned a value of 0.1 prior to transformation. Results were considered significant when the calculated $\mathrm{p}$-value was less than or equal to $\alpha=0.05$. 


\section{RESULTS}

\section{Aggregate size}

Aggregates ranged in size (long axis) from 1.9 to $3.7 \mathrm{~mm}$ with surface areas from 2.6 to $8.6 \mathrm{~mm}^{2}$ and volumes of 0.024 to $0.137 \mathrm{ml}$. The sets of 6 aggregates collected on each of the 5 sampling days were not significantly different in size (i.e. no relationship between sample day and size, $\mathrm{n}=30$ ) as measured by long axis $(p=0.095)$, area $(p=0.149)$, or volume $(p=0.903)$. Over the small range of aggregate sizes evaluated, surface area was weakly $\left(\mathrm{r}^{2}=0.160\right)$, but significantly $(\mathrm{p}=$ $0.016, \mathrm{n}=30$ ) related to average community metabolic response $(\triangle \mathrm{AWCD}$ ) and functional diversity (number of substrates used; $\mathrm{r}^{2}=0.101, \mathrm{p}=0.049, \mathrm{n}=30$ ) (Fig. 3A).

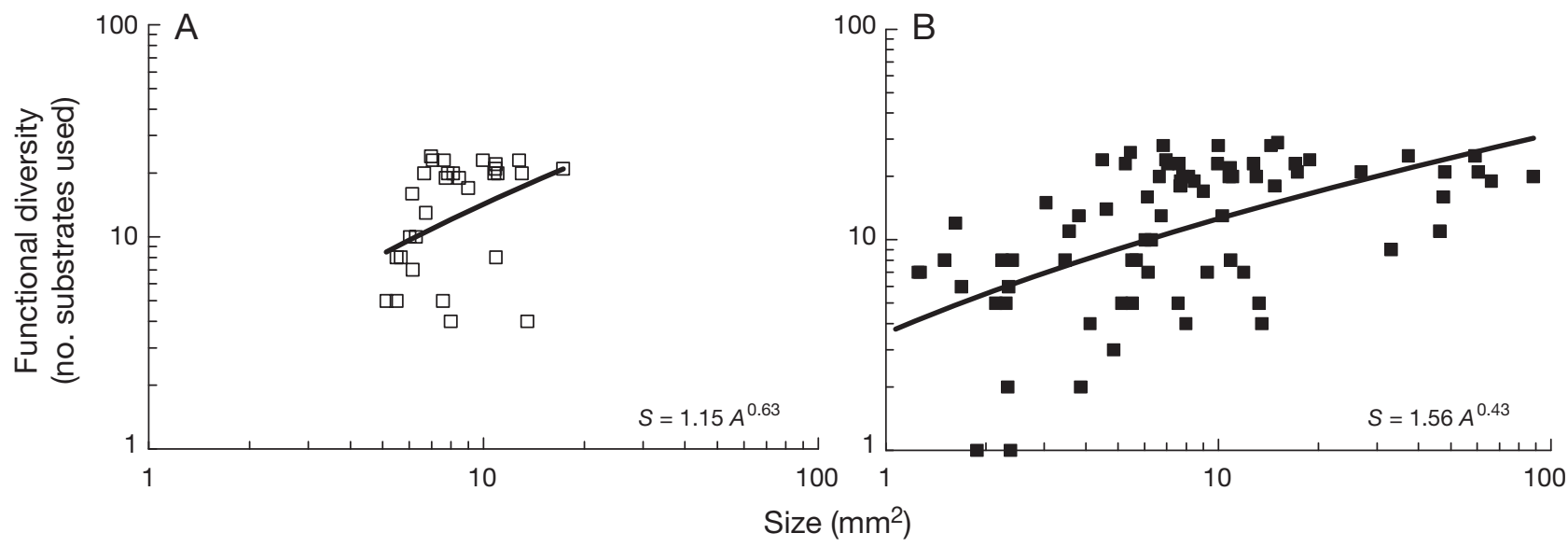

Fig. 3. Functional diversity (number of substrates used), a proxy for number of species (S), was significantly related to the size (area; $A$ in equations) for (A) aggregates surveyed in this experiment $(\mathrm{n}=30)$ and for $(\mathrm{B})$ all aggregates evaluated to date $(\mathrm{n}=79)$ (see 'Discussion: Species-area relationship' for details)
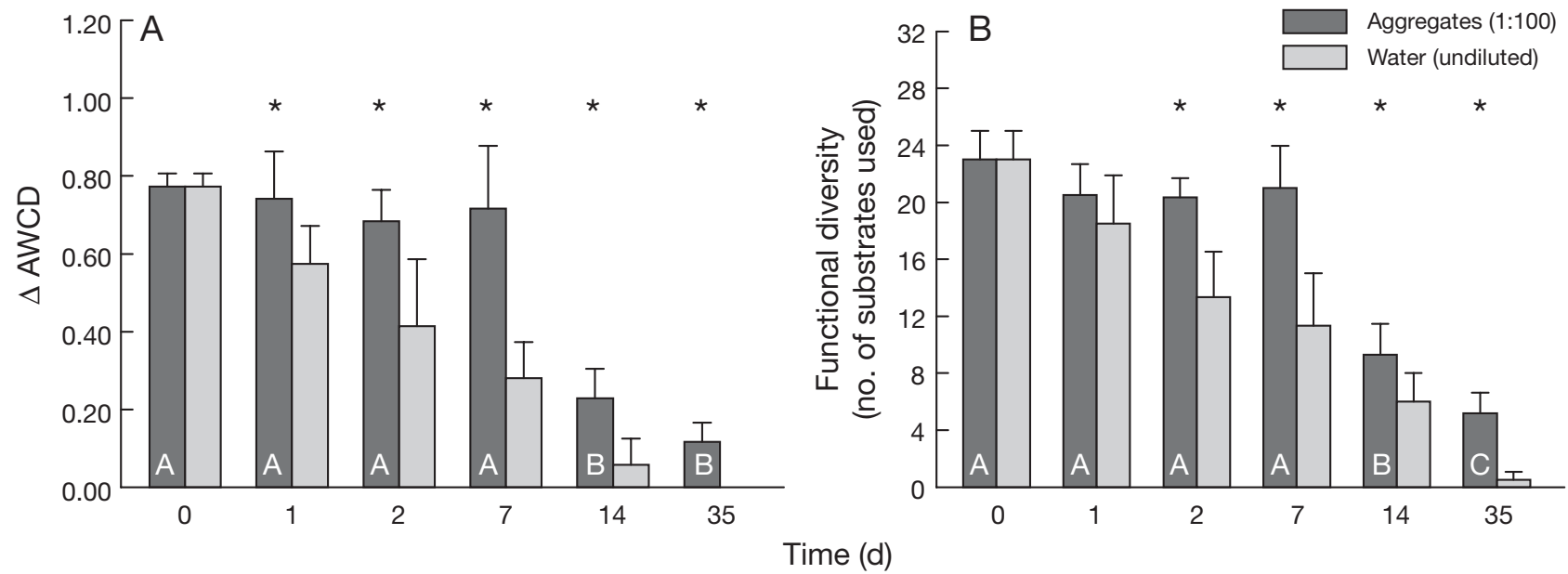

Fig. 4. (A) Community metabolic response, measured by $\triangle \mathrm{AWCD}$ (i.e. change in the average well color development), and (B) functional diversity, measured by the number of substrates used, remained relatively constant in aggregates (darker bars) for at least 1 wk (i.e. no significant differences for Days 0, 1, 2, 7) as compared to operationally defined 'aggregate-free' water (lighter bars) which steadily declined in both cases. Letters on darker bars: significantly different values among aggregates; $\star$ : significantly different concentrations between the aggregate-associated and the aggregate-free (water) microbial communities sampled at that time point. Significance was determined without factoring in the dilution of the aggregates ( 2 orders of magnitude) 
by microbes associated with aggregates. The metabolic response steadily declined in the water samples over the duration of the experiment, whereas the response in aggregates was maintained for at least $1 \mathrm{wk}$ (i.e. no significant differences among Days 0, 1, 2, 7) before declining on Days 14 and 35 (see letters on dark bars in Fig. 4A). The largest difference in response between the 2 types of microbial communities occurred on Day 7. Metabolic response was significantly related to all metrics of size including long axis $\left(\mathrm{r}^{2}=0.134, \mathrm{p}=0.027\right.$, $\mathrm{n}=30)$, surface area $\left(\mathrm{r}^{2}=0.160, \mathrm{p}=0.016, \mathrm{n}=30\right)$, and volume $\left(\mathrm{r}^{2}=0.146, \mathrm{p}=0.021, \mathrm{n}=30\right)$.

\section{Functional diversity}

Functional diversity (i.e. number of substrates used) varied from 0 to 24 (mean $\pm \mathrm{SD}: 13 \pm 8$ ) out of 31 substrates available. A 2-way ANOVA determined highly significant effects of Day $(\mathrm{p}<0.001, \mathrm{n}=$ 58), Sample type ( $\mathrm{p}<0.001, \mathrm{n}=58)$, and a significant interaction $(\mathrm{p}=0.004$, $\mathrm{n}=58$ ). For Day 1 (after $24 \mathrm{~h}$ in the rolling tank), there was no significant difference between the functional diversity of aggregate-associated and aggregate-free microbial communities $(p=0.251, n=58)$, but for all other time points, the functional diversity of the aggregate-associated microbial communities was significantly greater than that of its aggregate-free counterpart (Day 2: $\mathrm{p}=0.002$, Day 7: $\mathrm{p}=0.001$, Day 14: $p=0.020$, Day 35: $p=0.001$; see asterisks in Fig. 4B). Similar to results for community metabolic response detailed above, functional diversity of the microbial community in the water steadily declined from Day 0 to Day 35, whereas the functional diversity of the microbial communities in aggregates was maintained for at least 1 wk (no significant differences among Days 0, 1, 2, and 7, representing an equilibrium period for the aggregate-associated microbial community), before declining on Days 14 and 35. The largest difference in diversity between the aggregate-associated and aggregate-free microbial communities was on Day 7. For all samples (water and aggregates) the functional diversity of the microbial community was highly correlated with the average community metabolic response $(\mathrm{r}=$
0.98, $\mathrm{p}<0.001, \mathrm{n}=58$ ). Functional diversity of the aggregate-associated communities was also significantly related to long axis $\left(\mathrm{r}^{2}=0.105, \mathrm{p}=0.045\right)$ and surface area $\left(r^{2}=0.101, p=0.049\right)$, but not volume $(p=$ $0.066 ; \mathrm{n}=30$ in all cases).

\section{Species turnover}

Substrate utilization was analyzed for the 4 consecutive time points, i.e. Days $0,1,2$, and 7, when no significant differences in the functional diversity of aggregates were detected (Table 1). A total of 17 of the 31 carbon substrates were used at all 4 time points, whereas only 1 (2-hydroxy benzoic acid) of the 31 substrates was not used at all. Against this 'background' signal of relatively constant number of species (functional diversity being a proxy for species number), there was temporal variation in utilization of the
Table 1. Variation over time in the utilization of specific substrates by the aggregate-associated communities supports the concept of species turnover $(+=$ utilized, $0=$ not utilized). The proxy for number of species (functional diversity) remained relatively constant across the same 4 time points.

\begin{tabular}{|c|c|c|c|c|c|}
\hline Specific substrate & Substrate type & Day 0 & Day 1 & Day 2 & Day 7 \\
\hline Putrescine & Amine & + & + & + & + \\
\hline Phenylethylamine & Amine & + & 0 & 0 & + \\
\hline L-arginine & Amino acid & + & + & + & + \\
\hline L-asparagine & Amino acid & + & + & + & + \\
\hline L-phenylalanine & Amino acid & + & 0 & 0 & 0 \\
\hline L-serine & Amino acid & + & + & + & + \\
\hline L-threonine & Amino acid & + & + & + & + \\
\hline Glycyl-L-glutamic acid & Amino acid & + & + & + & + \\
\hline D-cellobiose & Carbohydrate & + & + & + & + \\
\hline$\alpha$-D-lactose & Carbohydrate & + & + & + & + \\
\hline$\beta$-methyl-D-lucoside & Carbohydrate & + & + & + & + \\
\hline D-xylose & Carbohydrate & + & + & + & 0 \\
\hline I-erythritol & Carbohydrate & + & + & + & + \\
\hline D-mannitol & Carbohydrate & 0 & + & + & + \\
\hline N-acetyl-D-glucosamine & Carbohydrate & + & + & + & + \\
\hline Glucose-1-phosphate & Carbohydrate & + & 0 & 0 & 0 \\
\hline D,L- $\alpha$-glycerol phosphate & Carbohydrate & + & + & + & + \\
\hline $\begin{array}{l}\text { D-galacturonic } \\
\text { acid- } \gamma \text {-lactone }\end{array}$ & Carbohydrate & + & + & 0 & 0 \\
\hline Pyruvic acid methyl ester & Carboxylic acid & 0 & + & + & + \\
\hline Glucosaminic acid & Carboxylic acid & + & 0 & 0 & 0 \\
\hline D-galacturonic acid & Carboxylic acid & 0 & + & + & + \\
\hline$\gamma$-hydroxybutyric acid & Carboxylic acid & + & + & + & 0 \\
\hline$\alpha$-ketobutyric acid & Carboxylic acid & + & 0 & 0 & + \\
\hline D-malic acid & Carboxylic acid & + & 0 & 0 & 0 \\
\hline Itaconic acid & Carboxylic acid & + & + & + & + \\
\hline 2-hydroxy benzoic acid & $\begin{array}{c}\text { Carboxylic acid/ } \\
\text { phenol }\end{array}$ & 0 & 0 & 0 & 0 \\
\hline 4-hydroxy benzoic acid & $\begin{array}{c}\text { Carboxylic acid/ } \\
\text { phenol }\end{array}$ & + & 0 & 0 & 0 \\
\hline Tween 40 & Polymer & + & + & + & + \\
\hline Tween 80 & Polymer & + & + & + & + \\
\hline$\alpha$-cyclodextrin & Polymer & + & + & + & + \\
\hline Glycogen & Polymer & + & + & + & + \\
\hline
\end{tabular}


remaining 13 substrates, evidence of species turnover in the aggregate-associated microbial communities. No consistent utilization pattern among the 6 substrate types was discernable.

\section{Variance to mean ratio (VMR) of functional diversity}

VMR values of the functional diversity for each set of 6 aggregates collected at each time point in the equilibrium period (i.e. Days 0 to 7 when no differences in functional diversity were detected) were all under the minimum value of 0.5 (Day $1=0.23$, Day $2=0.09$, Day $7=0.42$ ) predicted by the theory of island biogeography, supporting the notion that a non-random process generated the patterns observed.

\section{Concentration of culturable vibrios}

A 2-way ANOVA showed highly significant effects of Day ( $\mathrm{p}<0.001, \mathrm{n}=61)$, Sample type (aggregates $>$ water; $\mathrm{p}<0.001, \mathrm{n}=61$ ), and a significant interaction ( $p=0.027, n=61$ ) for sucrose-fermenting vibrios. For total vibrios, there were significant effects of Day $(\mathrm{p}<$ $0.001, \mathrm{n}=61$ ) and Sample type (aggregates $>$ water, $\mathrm{p}<0.001, \mathrm{n}=61$ ), but the interaction was not significant $(\mathrm{p}=0.074, \mathrm{n}=61)$. For both types of culturable vibrios, the highest concentrations occurred in aggregates sampled on Day 2 (Fig. 5). Culturable vibrios were detected in at least some aggregates sampled up to $35 \mathrm{~d}$, whereas no culturable vibrios were detected in any water samples after $2 \mathrm{~d}$. For the aggre- gate-associated microbial communities, functional diversity was significantly correlated with the concentration of both total vibrios $(\mathrm{r}=0.46, \mathrm{p}=0.011, \mathrm{n}=30)$ and sucrose-fermenting vibrios $(r=0.37, p=0.047, n=30)$, whereas community metabolic response ( $\triangle \mathrm{AWCD})$ was only correlated with the concentration of total vibrios ( $\mathrm{r}=0.44, \mathrm{p}=0.015, \mathrm{n}=30$ ) and not sucrose-positive vibrios $(r=0.35, p=0.058, n=30)$.

\section{Concentration of fecal indicator bacteria (Escherichia coli)}

A 2-way ANOVA indicated highly significant effects of Day ( $\mathrm{p}<0.001, \mathrm{n}=36)$, Sample type (aggregates $>$ water; $\mathrm{p}<0.001, \mathrm{n}=36$ ), and a significant interaction ( $\mathrm{p}<0.001, \mathrm{n}=36$ ) for concentrations of the fecal indicator bacteria, E. coli. Subsequently, using 1-way ANOVA on samples of aggregates only, concentrations on Days 1, 2, and 7 were significantly greater than the starting concentration (Day 0) and the concentrations on Days 14 and 35 (see letters above lines in Fig. 6).

\section{DISCUSSION}

The advantages of applying the theory of island biogeography to organic aggregates are plentiful. For example, aggregates (i.e. 'islands') are easily produced in the laboratory from a variety of environmental waters with relatively simple equipment, making aggregates conducive to island biogeography studies.
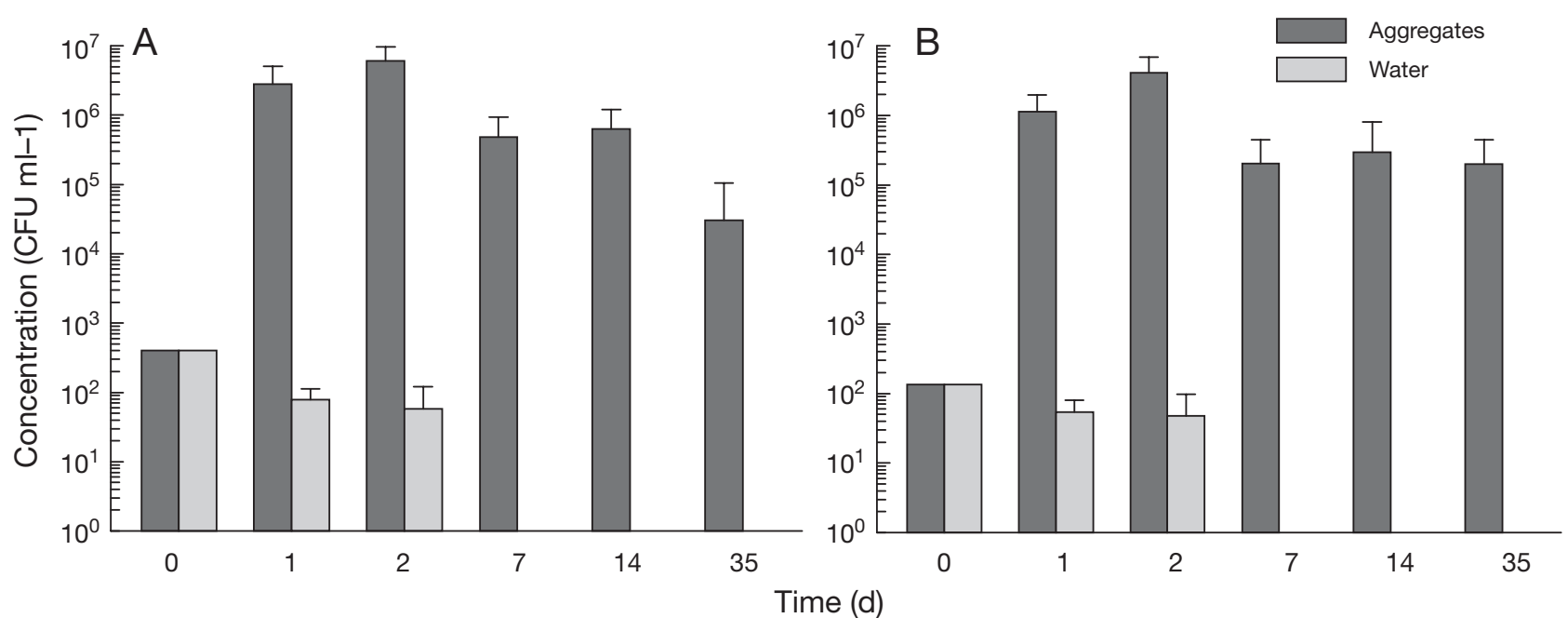

Fig. 5. Concentrations of vibrios (mean $\pm 1 \mathrm{SD}$ ) in aggregate-associated microbial communities (darker bars, $\mathrm{n}=6$ at each time point) and aggregate-free microbial communities (lighter bars, $\mathrm{n}=6$ at each time point) for both (A) total culturable vibrios and (B) sucrose-fermenting culturable vibrios. Concentrations of both microbe types increased in the first $2 \mathrm{~d}$ in aggregates, but not in water samples. Culturable vibrios were detected in at least some aggregates sampled up to $35 \mathrm{~d}$, whereas none were detected in water samples after $2 \mathrm{~d}$, suggesting the role of organic aggregates in the persistence of culturable vibrios in aquatic environments 


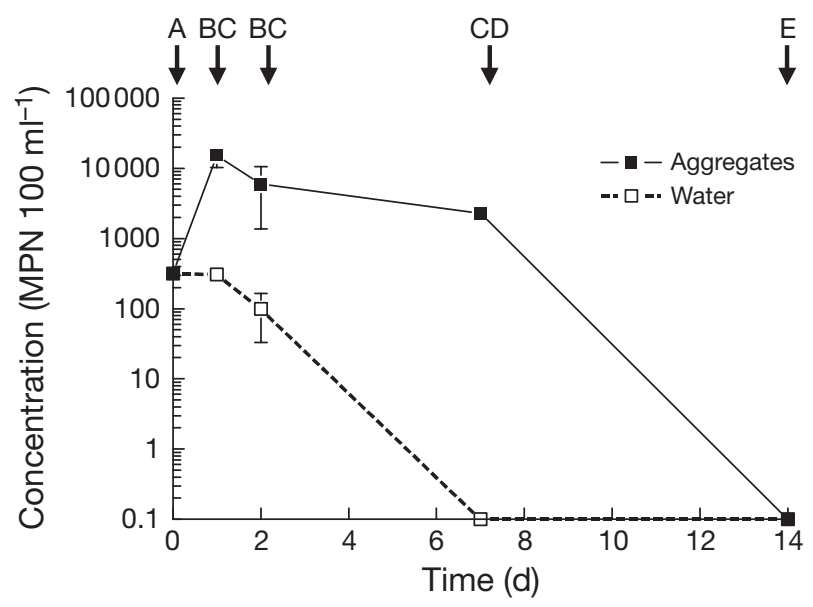

Fig. 6. Concentrations of Escherichia coli (mean $\pm 1 \mathrm{SD}$ ) in samples of aggregates compared to aggregate-free water. No signals (recorded as $<1$ MPN, i.e. most probable number) were detected in either type of sample on Days 14 or 35 (Day 35 not shown). Letters above the lines denote significantly different concentrations among the samples of aggregates, demonstrating that concentrations of E. coli on Days 1, 2 , and 7 were significantly higher than the starting concentration (Day 0). Given that positive results were detected in samples collected up to Day 7 for aggregates, but not for water, these results suggest a role for organic aggregates in the persistence of $E$. coli in aquatic environments

In addition, a large number of aggregates can be generated, yielding a greater number of replicates than is typically available with other island biogeography studies. Furthermore, since individual aggregateislands can be isolated, the entire island can be sampled to determine the number of species, compared to studies on oceanic islands (as archetypal examples) that rely on subsamples to infer species numbers. Finally, the microbial community of aggregate-islands can be manipulated, observed, and analyzed on substantially shorter time scales than corresponding studies of birds, mammals, or insects on islands. We are using island biogeography theory to better understand an important issue in applied ecology, that is, the transmission of waterborne diseases. The theory of island biogeography predictions that were evaluated in our research included species consistency, non-zero species turnover rates, species-area relationship, and variance to mean ratio of species number.

\section{Species consistency and non-zero level of species turnover}

Island biogeography predicts that the number of species on an island tends toward equilibrium because of a balance between immigration and extinction. We used functional diversity (i.e. number of substrates uti- lized) as a proxy for species diversity to evaluate the temporal consistency of species number and found no significant differences in the aggregate-associated communities on Days 1, 2, and 7. Analysis of the specific substrates utilized during this time period indicated a non-zero turnover of species (i.e. there were changes in species composition without changes in the number of species). The consistency of species number, coupled with non-zero turnover rates, supports the premise that a dynamic equilibrium within the aggregate-associated microbial community was reached within $1 \mathrm{~d}$ and was maintained for at least $1 \mathrm{wk}$. Whether or not an individual aggregate could remain intact and in suspension for $1 \mathrm{wk}$ in nature, is not known, but would most likely depend on the site- and time-specific hydrodynamics of the aquatic system in question. In addition, any period of dynamic equilibrium might be expected to vary with source water and season, but these variables were outside the scope of this experiment.

\section{Species-area relationship}

Island biogeography predicts that the relationship between the number of species (i.e. species richness, $S$ ) on an island and its area $(A)$ is a power function: $S=$ $C \times A^{z}$ (Fig. 3), where the constants $C$ and $z$ vary with taxonomic group, geography, and degree of isolation. Over the small size range of aggregates targeted in the present study ( 2 to $4 \mathrm{~mm}$ long), the species-area relationship was confirmed with a weak but significant relationship between size (in area) and functional diversity. Prior experiments by our group (M. M. Lyons \& F. C. Dobbs unpubl.), using the same methods, but with other sources of water over a wider range of aggregate sizes, support a more robust relationship (comparing Fig 3A to 3B). The species-area relationship documented in the present study supports other reports on the abundances of bacteria, flagellates, and ciliates scaling with the size of aggregates (Kiørboe 2003) and the existence of steep microbial speciesarea relationships (Bell et al. 2005).

\section{Variance to mean ratio (VMR) at equilibrium}

The 6 aggregates collected at each time point represent 6 islands that were similar in terms of source water, age, and size. In each set, the VMR of functional diversity was well below the 0.5 minimum predicted by the theory of island biogeography (MacArthur \& Wilson 1963, Brown \& Dinsmore 1988). In general, a VMR near 1.0 suggests that the number of resident species is due to a random process, whereas the further the VMR 
is away from 1, the more likely the process governing the number of species is not random (i.e. either a patchy distribution if VMR $>1$ or a patterned distribution if $\mathrm{VMR}<1$ ). In the case of island biogeography, the processes resulting in a patterned distribution are expected to be the balance of immigration and extinction rates.

\section{Aggregates as islands - application in disease ecology}

Although the details of the theory of island biogeography have been debated for some time (reviewed by Whittaker 2000), overall, the results of the present study support the idea that the theory applies to organic aggregates, which we have shown function as islands for bacteria. While arguing the relevance of the theory for microbial communities in aquatic environments, we have also demonstrated an elevated metabolic response and functional diversity of bacteria on individual organic aggregates compared to the surrounding water, supporting the concept that organic aggregates are favorable habitats surrounded by less favorable habitat. This result quantifies research describing organic aggregates as 'physically distinct benthic-like habitats' (Silver et al. 1978). Focusing on aggregates as islands is important in their context as potential reservoirs and vectors for aquatic pathogens (Lyons et al. 2005, Lyons 2008).

In aquatic ecosystems in general, the adhesion of bacteria to both biotic (e.g. phytoplankton, macrophytes, zooplankton, benthic invertebrates, pelagic vertebrates) and abiotic (e.g. clay particles, sediment grains, boat hulls, piers) surfaces is considered a protective mechanism for enhanced survival (Davies et al. 1995, Colwell et al. 1996, Lipp et al. 2002, Fries et al. 2006, 2007). Likewise, it has been proposed that aggregates might enhance the persistence of aquatic pathogens by providing a 'protective refuge' (Decho 2000) or a 'resource-rich microhabitat' (Cottingham et al. 2003), but prior to research presented herein, little data was available to support these ideas. We have demonstrated the relevance of the theory of island biogeography for microbial communities and simultaneously showed persistence of potential bacterial pathogens and fecal indicator bacteria in aggregates. For sewage-associated bacteria and naturally occurring pathogens such as vibrios, aggregates should enhance persistence, much as has been reported for bacteria associated with living plankton (Lipp et al. 2003, Cottingham et al. 2003, Signoretto et al. 2004). Indeed, we propose that when a planktonic organism dies and becomes part of a detrital aggregate, it brings with it a microbial community that persists even after the plankton has died. The same scenario would be expected for pathogens attached to sediment particles (Noble et al. 2006, Hartz et al. 2008) when they are resuspended and incorporated into aggregates.

An important application of our results is the decision framework that water quality managers use to make determinations about beach and shellfish bed closures. Specifically, our study shows that there is considerable variation in bacterial abundance among aggregates of the same age and similar size (Figs. 4 \& 5). Since aggregates are typically present in densities on the order of $1 \times 10^{0}$ to $1 \times 10^{3}$ per liter (see references in Simon et al. 2002), variation in water samples of $<11$ could be too high to reliably measure bacterial concentrations because the presence or absence of a single aggregate in an environmental water sample could drastically alter the measure of bacterial concentrations. In general, aggregates harbor bacteria at concentrations much higher than the surrounding waters with enrichment factors as high as 5700 per aggregate for non-pathogenic bacteria (Turley \& Mackie 1994). Enrichment factors for potentially pathogenic species were generally less than 500 (Lyons et al. 2007), but still significantly elevated compared to bulk water concentrations. Attachment to aggregates may ameliorate some of the effects of environmental stressors (e.g. sunlight, changes in temperature, salinity, $\mathrm{pH}$, and competition, and lack of nutrients; Sinton 2005), an idea that is supported by the results of the present study which show that Vibrio spp. and Escherichia coli associated with organic aggregates persist longer than their counterparts in aggregate-free water.

Aggregates also present a complication for modeling the transmission of waterborne diseases and illnesses from aquatic reservoirs to human hosts. At present, models do not consider the protection potentially provided to microorganisms by aggregates. We have shown that culturable vibrios proliferate in aggregates and decline in adjacent, aggregate-free water. Were these differences in population dynamics to be modeled, the presence or absence of aggregates would have profound effects on the model's predictions (McCallum et al. 2001, Eisenberg et al. 2002). This possibility is especially topical for models of Vibrio cholerae transmission (Koelle et al. 2005, Hartley et al. 2006, Pascual et al. 2006), given the well-recognized role of the aquatic reservoir in cholera dynamics (Codeço 2001). We therefore recommend that aggregates be incorporated into models of waterborne diseases and illnesses, similar to the way they have been added to models of carbon cycling and food webs (Azam \& Long 2001, Burd \& Jackson 2009).

In summary, we have provided evidence that organic aggregates function as islands for microbial communities. Aggregate-associated communities have 
elevated levels of metabolic response and functional diversity compared to their aggregate-free counterparts. We have also demonstrated higher concentrations and greater persistence of culturable Escherichia coli and vibrios in aggregate-associated microbial communities and suggest that these findings have applications to the field of disease ecology.

Acknowledgements. Funding for this research was provided by a collaborative NSF Ecology of Infectious Disease Grant to F.C.D. (\#0914429), J.E.W. (\#0914459), R.E.H. (\#0914450), and J.D. (\#0914347), along with a multidisciplinary seed funding grant from the Old Dominion Research Foundation to F.C.D. and H.G., and a NOAA Oceans and Human Health grant to JEW for the Interdisciplinary Research and Training Initiative on Coastal Ecosystems and Human Heath (I-RICH) which provided a post-doctoral research fellowship to M.M.L.

\section{LITERATURE CITED}

Alber M, Valiela I (1996) Utilization of microbial organic aggregates by bay scallops, Argopecten irradians (Lamarck). J Exp Mar Biol Ecol 195:71-89

Alldredge AL (1979) The chemical composition of macroscopic aggregates in two neritic seas. Limnol Oceanogr 24: 855-866

Alldredge AL (2000) Interstitial dissolved organic carbon (DOC) concentrations within sinking marine aggregates and their potential contribution to carbon flux. Limnol Oceanogr 45:1245-1253

Alldredge AL, Cohen Y (1987) Can microscale chemical patches persist in the sea? Microelectrode study of marine snow, fecal pellets. Science 235:689-691

Alldredge AL, Gotschalk CC (1990) The relative contribution of marine snow of different origins to biological processes in coastal waters. Cont Shelf Res 10:41-58

Alldredge AL, Silver MW (1988) Characteristics, dynamics and significance of marine snow. Prog Oceanogr 20:41-82

Azam F, Long RA (2001) Sea snow microcosms. Nature 414: 495-498

Azam F, Steward GF, Smith DC, Ducklow HW (1994) Significance of bacteria in carbon fluxes in the Arabian Sea. Proc Indian Acad Sci Earth Planet Sci 143:341-351

Bell T, Duane A, Song JI, Newman JA, Thompson IP, Lilley AK, Van der Gast CJ (2005) Larger islands house more bacterial taxa. Science 308:1884

Bochdansky AB, Herndl GJ (1992) Ecology of amorphous aggregates (marine snow) in the Northern Adriatic Sea. V. Role of fecal pellets in marine snow. Mar Ecol Prog Ser 89: 297-303

Bochner BR (1989) Sleuthing out bacterial identities. Nature 339:157-158

Brown M, Dinsmore JJ (1988) Habitat islands and the equilibrium theory of island biogeography: testing some predictions. Oecologia 75:426-429

Brzezinski MA, Alldredge AL, O'Brian LM (1997) Silica cycling within marine snow. Limnol Oceanogr 42: 1706-1713

Burd AB, Jackson GA (2009) Particle aggregation. Annu Rev Mar Sci 1:65-90

Bush MB, Whittaker B (1991) Krakatau: colonization patterns and hierarchies. J Biogeogr 18:341-356

> Caron DA, Davis PG, Madin LP, Sieburth JM (1986) Enrichment of microbial populations in macroaggregates (marine snow) from surface waters of the North Atlantic. J Mar Res 44:543-565

Cho BC, Azam F (1988) Major role of bacteria in biogeochemical fluxes in the ocean's interior. Nature 332:441-442

Choi KH, Dobbs FC (1999) Comparison of two kinds of Biolog microplates (GN and ECO) in their ability to distinguish among aquatic microbial communities. J Microbiol Methods 36:203-213

Christian BW, Lind OT (2006) Key issues concerning Biolog use for aerobic and anaerobic freshwater bacterial community-level physiological profiling. Int Rev Hydrobiol 91:257-268

Codeço CT (2001) Endemic and epidemic dynamics of cholera: the role of the aquatic reservoir. BMC Infect Dis 1:1

Colwell RR, Brayton P, Herrington D, Tall B, Huq A, Levine MM (1996) Viable but not-culturable Vibrio cholerae O1 revert to a cultivable state in the human intestine. World $\mathrm{J}$ Microb Biot 12:28-31

Colwell RR, Huq A, Islam MS, Aziz KMA and others (2003) Reduction of cholera in Bangladeshi villages by simple filtration. PNAS 100:1051-1055

- Cottingham KL, Chiavelli DA, Taylor RK (2003) Environmental microbe and human pathogen: the ecology and microbiology of Vibrio cholerae. Front Ecol Environ 1:80-86

Cowen JP, Silver MW (1984) The association of iron and manganese with bacteria on marine macroparticulate material. Science 224:1340-1342

Davies CM, Hong JAH, Donald M, Ashbolt NJ (1995) Survival of fecal microorganisms in marine and freshwater sediments. Appl Environ Microbiol 61:1888-1896

Decho AW (2000) Microbial biofilms in intertidal systems: an overview. Cont Shelf Res 20:1257-1273

Diamond JM (1969) Avifaunal equilibria and species turnover rates on the Channel Islands of California. Proc Natl Acad Sci USA 64:57-63

- Eisenberg JNS, Brookhart MA, Rice G, Brown M, Colford JM (2002) Disease transmission models for public health decision making: analysis of epidemic and endemic conditions caused by waterborne pathogens. Environ Health Perspect 110:783-790

> Eisma D, Bernard R, Cadée GC, Ittekkot V and others (1991) Suspended-matter particle size in some West-European estuaries. II. A review on floc formation and break-up. Neth J Sea Res 28:215-220

> Engel A, Szlosek J, Abramson L, Liu Z, Lee C (2009) Investigating the effect of ballasting by $\mathrm{CaCO}_{3}$ in Emiliania huxleyi. I. formation, settling velocities and physical properties of aggregates. Deep-Sea Res II 56:1396-1407

Fore SA, Guttman SI (1999) Genetic structure of Helianthus occidentalis (Asteraceae) in a preserve with fragmented habitat. Am J Bot 86:988-995

> Fowler SW, Knauer GA (1986) Role of large particles in the transport of elements and organic compounds through the oceanic water column. Prog Oceanogr 16:147-194

> Fries JS, Characklis GW, Noble RT (2006) Attachment of fecal indicator bacteria to particles in the Neuse River Estuary, N.C. J Environ Eng 132:1338-1345

Fries JS, Noble RT, Paerl HW, Characklis GW (2007) Particle suspensions and their regions of effect in the Neuse River Estuary: implications for water quality monitoring. Estuar Coasts 30:359-364

Garland JL, Mills AL (1991) Classification and characterization of heterotrophic microbial communities on the basis of patterns of community-level sole-carbon-source utilization. Appl Environ Microbiol 57:2351-2359

Gilbert FS (1980) The equilibrium theory of island biogeography: fact or fiction? J Biogeogr 7:209-235 
Grossart HP, Kiørboe T, Tang KW, Allgaier M, Yam EM, Ploug $H$ (2006) Interactions between marine snow and heterotrophic bacteria: aggregate formation and microbial dynamics. Aquat Microb Ecol 42:19-26

Guidi L, Jackson GA, Stemmann L, Miquel JC, Picheral M, Gorsky G (2008) Relationship between particle size distribution and flux in the mesopelagic zone. Deep-Sea Res Part I 55:1364-1374

Hartley DM, Morris JG, Smith DL (2006) Hyperinfectivity: A critical element in the ability of $V$. cholerae to cause epidemics? PLoS Med 3:e7 doi:10.1371/journal.pmed. 0030007

Hartz A, Cuvelier M, Nowosielski K, Bonilla TD and others (2008) Survival potential of Escherichia coli and Enterococci in subtropical beach sand: implications for water quality managers. J Environ Qual 37:898-905

Hebel D, Knauer GA, Martin JH (1986) Trace metals in large agglomerates (marine snow). J Plankton Res 8:819-824

Herndl GJ (1988) Ecology of amorphous aggregations (marine snow) in the Northern Adriatic Sea. II. Microbial density and activity in marine snow and its implication to overall pelagic processes. Mar Ecol Prog Ser 48: 265-275

Insam H, Goberna M (2004) Use of Biolog ${ }^{\circledR}$ for the community level physiological profiles (CLPP) of environmental samples. In: Kowalchuk GA, Bruijn FJ, Head IM, Akkermans $\mathrm{AD}$, van Elsas JD (eds). Molecular microbial ecology manual. Kluwer Academic Publishers, Dordrecht

> Jackson GA, Burd AB (1998) Aggregation in the marine environment. Environ Sci Technol 32:2805-2814

> Jones HL, Diamond JM (1976) Short-time-base studies of turnover in breeding bird populations on the Channel Islands of California. Condor 78:526-549

Kach DJ, Ward JE (2008) The role of marine aggregates in the ingestion of picoplankton-size particles by suspensionfeeding molluscs. Mar Biol 153:797-805

Kaltenböck E, Herndl GJ (1992) Ecology of amorphous aggregations (marine snow) in the Northern Adriatic Sea. IV. Dissolved nutrients and the autotrophic community associated with marine snow. Mar Ecol Prog Ser 87:147-159

Kebede M, Ehrich D, Taberlet P, Nemomissa S, Brochmann C (2007) Phylogeography and conservation genetics of a giant lobelia (Lobelia giberroa) in Ethiopian and tropical East African mountains. Mol Ecol 16:1233-1243

Kinkel LL, Andrews JH, Berbee FM, Nordheim EV (1987) Leaves as islands for microbes. Oecologia 71:405-408

Kiørboe T, Hansen JLS (1993) Phytoplankton aggregate formation: observations of patterns and mechanisms of cell sticking and the significance of exopolymeric material. J Plankton Res 15:993-1018

Kiørboe T (2001) Formation and fate of marine snow: smallscale processes with large-scale implications. Sci Mar 65: $57-71$

Kiørboe T (2003) Marine snow microbial communities: scaling of abundances with aggregate size. Aquat Microb Ecol 33: $67-75$

Kiørboe T, Thygesen UH (2001) Fluid motion and solute distribution around sinking aggregates. II. Implications for remote detection by colonizing zooplankters. Mar Ecol Prog Ser 211:15-25

Koelle K, Rodo X, Pascual M, Yunus M, Mostafa G (2005) Refractory periods to climate forcing in cholera dynamics. Nature 436:696-700

- Lampitt RS, Hillier WR, Challenor PG (1993) Seasonal and diel variation in the open ocean concentration of marine snow aggregates. Nature 362:737-739

Lipp EK, Huq A, Colwell RR (2002) Effects of global climate on infectious disease: the cholera model. Clin Microbiol Rev 15:757-770

Lipp EK, Rivera IN, Gil AI, Espeland EM and others (2003) Direct detection of Vibrio cholerae and ctxA in Peruvian coastal water and plankton by PCR. Appl Environ Microbiol 69(6):3676-3680

Logan BE, Hunt JR (1987) Advantages to microbes of growth in permeable aggregates in marine systems. Limnol Oceanogr 32:1034-1048

Lomolino MV, Brown JH, Davis R (1989) Island biogeography of montane forest mammals in the American Southwest. Ecology 70:180-194

Lyons MM (2008) The role of marine aggregates in the ecological epizootiology of Quahog Parasite X (QPX) disease in Northern Quahogs (= Hard Clams) Mercenaria mercenaria. PhD Dissertation, University of Connecticut, Groton, $\mathrm{CT}$

Lyons MM, Ward JE, Smolowitz R, Uhlinger KR, Gast RJ (2005) Lethal marine snow: pathogen of bivalve mollusc concealed in marine aggregates. Limnol Oceanogr 50: $1983-1988$

> Lyons MM, Lau Y, Carden WE, Ward JE and others (2007) Characteristics of marine aggregates in shallow-water ecosystems: implications for disease ecology. EcoHealth 4 : 406-420

MacArthur RH, Wilson EO (1963) An equilibrium theory of insular zoogeography. Evolution 17:373-387

MacArthur RH, Wilson EO (1967) The Theory of Island Biogeography. Princeton University Press, Princeton, NJ

- McCallum H, Barlow N, Hone J (2001) How should pathogen transmission be modeled? Trends Ecol Evol 16:295-300

Noble R, Characklis G, Fries JS, Hsieh JL (2006) Assessing the role of particle attachment in fate and transport of microbial indicators and pathogens in an eutrophic estuary. Am Soc Limnol Oceanogr Ocean Sci Meet, February 20-24, 2006, Honululu, HI

Ohmura Y, Kawachi M, Kasai F, Watanabe MM, Takeshita S (2006) Genetic combinations of symbionts in a vegetatively reproducing lichen, Parmotrema tinctorum, based on ITS rDNA sequences. Bryologist 109:43-59

$>$ Pascual M, Koelle K, Dobson AP (2006) Hyperinfectivity in cholera: A new mechanism for an old epidemiological model? PLoS Med 3:e280 doi:10.1371/journal.pmed. 0030280

Ploug H, Grossart H, Azam F, Jørgensen BB (1999) Photosynthesis, respiration and carbon turnover in sinking marine snow from surface waters of Southern California Bight: implications for the carbon cycling in the ocean. Mar Ecol Prog Ser 179:1-11

Ploug H, Iversen HM, Fischer G (2008) Ballast, sinking velocity, and apparent diffusivity within marine snow and zooplankton fecal pellets: implications for substrate turnover by attached bacteria. Limnol Oceanogr 53: 1878-1886

> Reche I, Pulido-Villena E, Morales-Baquero R, Casamayor EO (2005) Does ecosystem size determine aquatic bacterial richness? Ecology 86:1715-1722

Riebesell U (1991) Particle aggregation during a diatom bloom. II. Biological aspects. Mar Ecol Prog Ser 69:281-291

Riley GA (1963) Organic aggregates in seawater and the dynamics of their formation and utilization. Limnol Oceanogr 8:372-381

> Shanks AL, Edmondson EW (1989) Laboratory-made artificial marine snow: a biological model of the real thing. Mar Biol 101:463-470

> Shanks AL, Trent JD (1979) Marine snow: microscale nutrient patches. Limnol Oceanogr 24:850-854 
Shanks AL, Walters K (1997) Holoplankton, meroplankton, and meiofauna associated with marine snow. Mar Ecol Prog Ser 156:75-86

Signoretto C, Burlacchini G, del Mar Lléo M, Pruzzo C and others (2004) Adhesion of Enterococcus faecalis in the nonculturable state to plankton is the main mechanism responsible for persistence of this bacterium in both lake and seawater. Appl Environ Microbiol 70: 6892-6896

Silver MW, Alldredge AL (1981) Bathypelagic marine snow: deep-sea algal and detrital community. J Mar Res 39: 501-530

Silver MW, Shanks AL, Trent JD (1978) Marine snow: microplankton habitat and source of small-scale patchiness in pelagic populations. Science 201:371-373

Silver MW, Coale SL, Pilskaln CH, Steinberg DR (1998) Giant aggregates: importance as microbial centers and agents of material flux in the mesopelagic zone. Limnol Oceanogr 43:498-507

Simberloff DS, Wilson EO (1970) Experimental zoogeography of islands: a two-year record of colonization. Ecology 51: 934-937

Simon M, Grossart H, Schweitzer B, Ploug H (2002) Microbial ecology of organic aggregates in aquatic ecosystems. Aquat Microb Ecol 28:175-211

Sinton LW (2005) Survival of enteric bacteria in seawater: biotic and abiotic factors. In: Belkin SS, Colwell RR (eds) Oceans and health: pathogens in the marine environment. Springer, New York

Sokal RR, Rohlf FJ (1981) Biometry, 2nd ed. W. H. Freeman, New York

Stemmann L, Prieur L, Legendre L, Taupier-Letage I, Picheral M, Guidi L, Gorsky G (2008) Effects of frontal processes on marine aggregate dynamics and fluxes: an interannual study in a permanent geostrophic front (NW Mediter-

Editorial responsibility: Gerhard Herndl, Vienna, Austria ranean). J Mar Syst 70:1-20

Stevens H, Simon M, Brinkhoff T (2009) Cultivable bacteria from bulk water, aggregates, and surface sediments of a tidal flat ecosystem. Ocean Dyn 59:291-304

Thornton I (1996) Krakatau: The destruction and reassembly of an island ecosystem. Harvard University Press, Cambridge, MA

Thornton DCO (2002) Diatom aggregation in the sea: mechanisms and ecological implications. Eur J Phycol 37: 149-161

Turley CM, Mackie PJ (1994) Biogeochemical significance of attached and free-living bacteria and the flux of particles in the NE Atlantic Ocean. Mar Ecol Prog Ser 115:191-203

> Turner JT (2002) Zooplankton fecal pellets, marine snow, and sinking phytoplankton blooms. Aquat Microb Ecol 27: $57-102$

Venkateswaran K, Kiiyukia C, Nakanishi K, Nakano H, Matsuda O, Hashimoto H (1990) The role of sinking particles in the overwintering process of Vibrio parahaemolyticus in a marine environment. FEMS Microbiol Lett 73: $159-166$

- Ward JE, Kach DJ (2009) Marine aggregates facilitate ingestion of nanoparticles by suspension-feeding bivalves. Mar Environ Res 68:137-142

> Whittaker RJ (2000) Scale, succession and complexity in island biogeography: Are we asking the right questions? Glob Ecol Biogeogr 9:75-85

Wilson EO (1959) Adaptive shift and dispersal in a tropical ant fauna. Evolution 13:122-144

Yam EM, Tang KW (2007) Effects of starvation on aggregate colonization and motility of marine bacteria. Aquat Microb Ecol 48:207-215

Zak JC, Willig MR, Moorhead DL, Wildman HG (1994) Functional diversity of microbial communities: a quantitative approach. Soil Biol Biochem 26:1101-1108

Submitted: January 8, 2010; Accepted: March 10, 2010

Proofs received from author(s): 29.04.2010 